Makale Geliş | Received: 17.07.2019

Mavi Atlas, 7(2)/2019: 28-53

Makale Kabul | Accepted: 08.08.2019

DOI: $10.18795 /$ gumusmaviatlas.592866

Araştırma Makalesi | Research Article

\begin{abstract}
Zehra YAZBAHAR
Dr. Öğr. Üyesi| Assist. Prof. Dr. Gümüşhane Üniversitesi, Edebiyat Fakültesi, Türk Dili ve Edebiyatı Bölümü, Gümüşhane-TÜRKIYYE Gumushane University, Faculty of Letters, Department of Turkish Language and Literature, Gumushane-TURKEY

ORCID: 0000-0003-0419-1660

zehra-yazbahar@hotmail.com
\end{abstract}

\title{
Murathan Mungan'ın Şairin Romanı İsimli Eserinin Yapısalcı Metodoloji Çerçevesinde İncelenmesi
}

$\ddot{O} z$

Edebî eseri anlamak ya da anlamlandırmak için ortaya atılan pek çok yöntem ve kuram vardır. Esere anlam kazandırmaya çalışan bu yöntemlerden biri de yapısalcılıktır. Batı dünyasında "structuralism" olarak bilinen, temelinde Rus biçimciliğinin olduğu ve 20. yüzyılda ortaya çıkan yapısalcı yöntemde incelenen herhangi bir nesnenin kendi içinde anlaşılabilir olmasını sağlamak esastır. Genel hatlarıyla nesneyi "yapı" kavramından hareketle açıklamaya çalışan bu kuramın özünü oluşturan ana öge, yapıdır. Edebî eser bazında düşündügüumüzde ise her eser, bütünlük arz eden çeşitli yapı unsurlarından oluşur. Eserde anlam bütünlügüüü sağlayan yapıyı "anlatıcı", “olay örgüsü”, "kişiler”, “zaman”, "mekân”, "dil ve üslup” gibi unsurların meydana getirdiği söylenebilir. Yapısalcılık kuramı doğrultusunda Murathan Mungan’ın 2011 yılında yayımlanan Şairin Romanı isimli eserinin ele alındığı bu çalışmada söz konusu eser, "anlatıcı ve anlatma yöntemi”, "içerik", “olay örgüsü ve vaka takdimi”, "dil ve üslup” unsurları yönünden incelenmiştir. Diğer bir ifadeyle yapı unsurları arasındaki ilişki verilerek romanın kurgusal özellikleri tespit edilmeye çalışılmış ve romanın yapısal çözümlemesi yapılmıştır.

Anahtar Kelimeler: Murathan Mungan, Şairin Romanı, Yapısalcılık, Yapısalcı Çözümleme, Roman Tekniği.

\section{Examination of The Murathan Mungan's Şairin Romanı in the Frame of Structuralist Methodology}

\begin{abstract}
There are many methods and theories to understand or make sense of the literary work. One of these methods that try to give meaning to it is structuralism. There is Russian formality on the basis of what is known as "structuralism" in the Western world and it is essential to make any phenomenon which is examined by structuralist method that emerged in the 20th century understandable in itself. The main item that constitutes the essence of this theory is the structure and the theory attempts to explain the phenomena in general with the motive of "structure". On the other hand, every work is composed of various structural elements which are integral when considering the context of literary work. We can say that items such as "narrator", "event", "people", "time", "space", "language and wording" create the structure that ensures content integrity in the work. In our work which addressed the work named Şairin Romanı published by Murathan Mungan in 2001 in line with structuralism approach, it was analysed in terms of the elements "narrator and narrating method", "content", "storyline and abstract", "language and wording". In other words, the fictional features of the novel are tried to determine and structural analysis of it was done thereby revealing the relationship between the items of the structure of the novel.
\end{abstract}

Keywords: Murathan Mungan, Şairin Romani, Structuralism, Structuralist Analysis, Novel Technique. 


\section{Zehra YAZBAHAR, "Murathan Mungan'ın Şairin Romanı İsimli Eserinin Yapısalcı Metodoloji Çerçevesinde İncelenmesi”, Mavi Atlas, 7(2)/2019: 28-53}

\section{Giriş}

Günümüz Türk edebiyatının önemli isimlerinden biri olan Murathan Mungan; roman, hikâye, şiir, tiyatro, senaryo, sinema eleştirisi, deneme, seçki, eleştiri gibi birçok alanda eser veren bir sanatkârdır. Yazıya tiyatro ve şiirle başlayan Mungan; hikâyeleriyle yazma sanatını geliştirir, romanları ve denemeleriyle de edebî hayatını devam ettirir. "Her yerde hep iğreti, hep yabancı, hep sürgün gibi duran benim, yıllardır içimde yaralı bir hayvan gibi saklanan yalnızlığımı büyütmüştü bu 'üvey' kimliğiyle hayatımı damgalayan yeni gerçek. Sonrasında kabaca söylersek: Hayattan kaçtım, sanata sığındım. Yazı'yı evlat edindim, okurları akraba..." (Mungan 2005: 75) sözleriyle edebî kişiliğinin geçmiş hayatında yaşadıklarıyla şekillendiğini belirten Mungan'ın annesinin öz annesi olmadığını öğrenmesi, hayatındaki önemli dönüm noktalarından biridir. Öyle ki bu durum, Mungan'a "eğreti olma” hissini yaşatır. Bunun neticesinde de hayatı boyunca üzerindeki üvey olma kimliğini atamaz ve ruh dünyasındaki yabancılığı ya da eğretiliği, edebiyata sığınarak yazıyla yenmeye çalışır.

Edebiyatçının hem yalnızlığa hem de kapanmaya ihtiyacı olduğunu düşünen ve yazarın roman yazarken aslında ne okumak istediğini de yazdığını ifade eden Mungan, iyi bir roman yazarının okuru söylediği her şeye inandırarak etkilemesi gerektiğini söyler. Günlük hayattan aldığı hikâyelerle yazan Mungan'ın “hayattan beslenen bir yazar olarak gözü her yerde, kulağı insanların diyaloglarındadır.” (Şabaş 2014: 10). Diğer bir ifadeyle günlük yaşamın ona sunduğu malzemeyi kullanır ve çoğu zaman etkilendiği veya onda iz bırakan kişileri, eserlerinde yaşatır. Edebiyatı "eski zaman sanatı", kendini de "eski zaman sanatını iş edinmiş biri" olarak görür ve gündelik yaşamdan beslenmesinin yanında farklı tekniklere yer vererek okurun karşısına zengin bir anlatımla çıkar. Hemen hemen her eserinde metinlerarasılıktan yararlanır. Bununla birlikte metinlerarası yolculuk olarak değerlendirdiği eserlerinde yolculuğun olası gizlerini, saklı işaretlerini ya da dönüşümlü simgelerini, gerekli konaklama yerlerine ve yol ayrımlarına bırakıp okurun bunları bulmasını ister (Mungan 2010: 8). Özellikle Doğu kültürü, masal, halk hikâyesi, şiir, mitoloji gibi kaynaklardan beslenerek eserlerini oluşturan Mungan, tarihî ve mitolojik motifleri kişisel duygularla ilişkilendirerek yazar. İnsanın yalnızlı̆̆ı, iş sıkıntıları, kimlik bunalımları, umutları vb. konuların dışında toplumsal sorunları da ele alan sanatkâr, hayal gücü ile gerçeği birleştirerek kendine özgü dil ve anlatım teknikleriyle edebiyat dünyasında önemli bir yer edinir. 


\title{
Romanın Yapısal Çözümlemesi
}

\author{
"Bir yazar için, bir ilişkiden geriye \\ yalnızca yazdıkları kalıyor. Belki de bu kadar \\ sevmesem, bu kadar yazamazdım." \\ Murathan Mungan \\ (Alak 2009: 8)
}

Üzerinde on beş yıl çalıştığ Şairin Romanı isimli eserinin türü için "fantezi roman" diyen Murathan Mungan, eserinde roman formunu kullanarak şiire dair görüşlerini açıklar. Yani kurmaca metnin merkezine şiir sanatını yerleştirerek bir bakıma kendi poetikasını oluşturur. Mungan'ın “şiirin, romanın, edebiyatın öldüğü, giderek yazılı kültürün bile tükenmekte olduğu her şeyin görselliğe indirgendiği bir çağda, dilin kadim sanatı şiire, roman aracılığıyla bir saygı duruşu" (Erciyes 2011) olarak tanımladığı Şairin Romanı, "anlatımıyla, hikâyesiyle, meselesiyle yalnızca yazarın başyapıtı değil, türün de en iyi örneklerinden biridir.” (Erciyes 2015). Romanın yapısal çözümlemesine geçmeden önce yapısalcılık hakkında kısaca bilgi vermek yerinde olacaktır:

1960’l1 yıllarda Fransa'da Tzvetan Todorov, Algirdas Julien Greimas, Gérard Genette, Henri Brémond, Roland Barthes temsilciliğinde ortaya çıkan ve temelinde Rus Biçimciliği'nin -dolayısıyla Ferdinand de Saussure'ün- olduğu yapısalcılık, özellikle Saussure'ün dilbilim çalışmalarından etkilenen çözümleme yöntemlerindendir. $\mathrm{Bu}$ çözümlemeyi daha net anlayabilmemiz için Saussure'ün “dil ile söz ayrımı”ndan bahsetmemiz gerekir. Saussure'e göre dil bir sistemdir ve Türkçe, İngilizce, Almanca, Fransızca dediğimizde dili kastetmiş oluruz. Söz ise dilin somut kullanımıdır. Nasıl Saussure'ün dilbiliminde somut ve bireysel sözün arkasında onu belirleyen soyut ve toplumsal bir dil varsa edebiyatta da sözün arkasında edebiyat sistemi vardır. Saussure'ün dili incelemek için dış gerçekliğe başvurmaması gibi yapısalcı çözümleme de edebî eseri incelemek için tarih, köken, gelişim, sosyoloji, felsefe gibi art zamansal sorunlarla yani metin dışı unsurlarla ilgilenmez. Zira metin, tarih içindeki gelişimi ele alınarak değil de eş zamanlılık içinde incelenmelidir. Diğer bir ifadeyle bu yöntem bir metni incelerken onun oluşumuna ya da tarihçesine değil, metnin yapısal özelliklerine bakar. Bununla birlikte yapısalcı metodoloji çerçevesinde metin incelenirken belirgin bir yol takip edilir. Metin; "anlam bilimi”, "söz dizimi”, "söyleniş biçimi” gibi birim parçalara bölünerek incelenir ve bu inceleme sonucunda metnin kendine has yöntemleri bulunup metin yorumlanır. Yapısalcı incelemede iki amaç vardır: 1. Metnin iskeletini ortaya çıkararak metni betimlemek. 2. Metnin iskeletini ortaya çıkararak metnin özelliğini ve yapısını 


\section{Zehra YAZBAHAR, “Murathan Mungan'ın Şairin Romanı İsimli Eserinin Yapısalcı Metodoloji Çerçevesinde İncelenmesi”, Mavi Atlas, 7(2)/2019: 28-53}

bulmaya çalışmak. Yani yapısalcılığa göre birimlerden oluşan bir bütün olan metin, sadece kendisi için incelenmelidir. ${ }^{1}$

Şiirin müziğinin romanın her satırında duyulduğunu düşünen Ayşe Arman, Mungan'la yaptığı röportajda uzun bir yazım süreci olan romanı "Yüzeyselliğin, tek düzeliğin tavan yaptığ 1 bir dünyada bambaşka bir çiçek açıyor hayatınızda. Ve üstelik okunduktan sonra hemen bir kütüphane rafına kaldırılacak bir kitap değil, her aklınıza düştüğünde, 'kelimelerin efendisi'nin kelimelerine dokunmak isteyeceksiniz." (Arman 2011) sözleriyle tanıtır. Öyle ki Mungan'ın yazdığı bu romanla imgeden bizzat gerçekliğe geçtiğini; romanında şiirselliğin, yoğunluğun ya da dil bilincinin en üst seviyede olduğunu belirten Necip Tosun'a göre de romanın dilinde, kurgusunda ve bakış açısında Mungan'in şair duruşu hissedilir.

Mungan, “(H)iç şüphesiz şiirinin 'roman'ını yazar ve toplumsal yaşama, insan ilişkilerine, hayatın kendisine daha somut bir şekilde yaklaşır. Artık tek bir manzaraya değil, bütün bir kente, dünyaya bakmaktadır." (Tosun 2012). Şairin Romanı'nın² Türk edebiyatındaki yerini yapısalcı kuram çerçevesinde daha iyi kavrayabilmek için romanı yapısalcı çözümlemeye uygun olarak "anlatıcı ve anlatma yöntemi”, "içerik", "olay örgüsü ve vaka takdimi”, "şiir hakkındaki düşünceler ile dil ve üslup” olmak üzere toplam dört alt başlık altında inceledik:

\section{Anlatıcı ve Anlatma Yöntemi}

\section{- Anlatıcı ve Bakış Açısı}

Olayları aktarırken ya da roman kişileri hakkında bilgiler verirken tanrısal konumlu gözlemci anlatıcıyı kullanan Murathan Mungan'ın okuyucunun karşısına her şeye vakıf kişiliğiyle çıkarttığı anlatıcı hem dışarıdan bir gözlemci olarak yaşanan her şeyi izleyip duyarak konuşmaları takip eder hem de roman kişilerinin iç dünyalarında neler olup bittiğini, zihinlerinden neler geçtiğini en ince ayrıntısına kadar bilir. Diğer bir ifadeyle anlatıcının bilgisi sınırsızdır ve anlatıcı, romanda yer alan olay ya da kişiler hakkında geniş ve çok yönlü her türlü bilgiye sahiptir: “Ümma ve Lelalu, Anakara'nın en meşhur iki kadın şairiydi. Birbirinden uzak sayılabilecek iki ayrı şehirde, biri Ajnera'da, diğeri Micla'da yaşıyor; birbirlerini daha çok şiirlerinden tanıyorlardı.” (s. 15). Alıntıda roman kişilerinden Ümma ve Lelalu, romanın dışında kalan bir gözlemci figür tarafından

\footnotetext{
${ }^{1}$ Yapısalcı çözümleme ile ilgili yararlanılan kaynaklar için bakınız: Moran 2007: 185-198, Bayrakdar 2008, Say 2013, Berk ve Yildırım 2015.

2 Makalemizde, romanın Metis Yayınları tarafından 2011 yılında yayımlanan baskısı esas alınmıştır. Romandan yaptığımız alıntıların sayfa numarası, bu baskıya aittir.
} 
anlatılır. Anlatıcı, romanda bahsi geçen bu iki kadın şairde olduğu gibi diğer roman kişilerinin de yaşamlarını sergileyerek olay örgüsünü verir ve olan biteni izleyerek roman kişilerinin zihninden geçenleri ya da iç dünyalarını bilip bunu okuyucuya sunar. Sadece anlatı zamanında cereyan etmekte olan hadiseler hakkında değil, roman kişilerinin geçmişteki yaşantıları hakkında da bilgi sahibidir ve gerekli gördüğü yerlerde geriye dönerek roman kurgusunu anlaşılır kılacak bilgileri okuyucuya aktarır. Anlatıma doğrudan müdahale edip adeta bir bilinç olarak roman dünyasında dolaşır ve okuyucunun karşısına romanın bütününe, olay örgüsüne, kişilerin fiziksel görünüşleri ile iç dünyalarına, soyut ve somut mekâna, zamanın öncesi, şimdisi ve sonrasına hâkim kişiliğiyle çıkar.

Her şeyin farkında olan ve her şeyi bilen anlatıcının kullanıldığı romanda anlatıcı, olay veya kişileri yansıtırken bazen kendi omuzunda kullandığı kamerayı bazen de roman kahramanlarının omuzuna yükler:

Yüz yüzeydiler şimdi. İkisi de aynı nedenle ürkmüştü. Kendilerini biraz farklı gösteren bir aynaya bakıyor gibiydiler. Gamenn'in bir anda bütün kanı çekilmişti. Yazgının kötücül bir şakasının kurbanı olmanın sersemletici inanmazlığıyla bakıyordu karşısında duran adama. Nihayet rüyasından uyanmış, ama kendisini başka bir rüyanın içinde bulmuştu. Bu, oydu. Hem oydu, hem başkası. Yüzünde onları ayıran yaradan daha fazla bir şey vardı; tüm yaşadıkları yüzüne onu başkalaştıran sert bir kabuk kazandırmış gibiydi. (s. 558).

Gamenn'in öldü sandığı ikiz kardeşi Tagan'la karşılaştığında hissettiklerine yer verilen alıntıdan anlaşılacağı üzere gözlemci anlatıcı, romanda yer alan Gamenn'in duygu ve düşüncelerini yine Gamenn'in bakış açısıyla verir. Yer yer olayları ve kişileri roman kişilerinin kamerasından sergileyen anlatıcı tarafından seçilen bu kişiler, yazarın yansıtıcı bilinçleridir.

Bir roman kişisinin bakış açısıyla eksik verilen bir olay ya da kişi, başka kişilerin anlatımıyla da verilerek romanın hikâyesinde bütünlük sağlanır. Murathan Mungan, bu sayede hem kişilere konuşması için firsat tanımış olur hem de okuyucunun roman kişilerinin penceresinden bakmasını ve onları daha iyi tanımasını sağlar. Öyle ki verdiğimiz alıntıda yansıtıcı bilinç olarak seçilen Gamenn'in gözüyle öldü sandığ i ikiz kardeşi Tagan'la karşılaştığında yaşadıkları sunularak roman kişisinin onun ağzından ve onun cümleleriyle tanınmasına olanak tanınır. Bu yapılırken de okuyucunun olaylara ve kişilere değişik bakış açılarıyla bakılmasına yardımcı olunur. Mungan, tanrısal gözlemci anlatıcı tipini kullandığı romanında kendini belli etse bile romandaki çok seslilik ve çeşitlilikle romana yorum zenginliği katar. 


\section{- Aktarma Yöntemleri}

Modern teknikleri kullanarak dikkatleri olay örgüsü ve roman kişileri üzerine çeken yazar, geçmişe dayalı anlatma tekniğiyle şimdiye dayalı gösterme tekniğini bir arada vererek geçmiş ile şimdinin bir araya getirilmesinde geçişleri kolaylaştırır. Diğer bir ifadeyle romanını aktarırken anlatıcıyı kullandığı anlatma yöntemini ve olay ya da kişileri temsil yoluyla sergileyip verdiği gösterme yöntemini tercih eder.

\section{Anlatma Yöntemi (Diegesis)}

Olayları yorumlayarak roman kişileri ya da meydana gelen hadiseler hakkında değerlendirmeler yapan anlatıcı, yer yer roman kişileri ve olaylar karşısında tarafsız kalmayı başaramaz: "Düşmanlarının, yabancıların ruhunu okumasına izin vermeyen kilitli bir bedeni vardı Serhenas'1n. Bu yüzden iyi bir savaşçıdı. Bir savaşı göz ucuyla kazanacak kadar ustalaşmış, Settu'nun ordusuna kabul edilene kadar altmış kadar kayıtlı döğüşten galip çıkmıştı.” (s. 250). Alıntıda, anlatıcının açıklamalarıyla gerçekleştirilen klasik bir karakterizasyon uygulaması vardır. Karakter çiziminde Serhenas ile alakalı bilgiler, bizzat anlatıcı tarafından açıklama ya da anlatma yöntemiyle verilir. Diğer bir ifadeyle roman kişilerinden Serhenas'1 tanıtırken yorumu okuyucuya birakmayan anlatıcı, onun hakkındaki düşüncelerini bizzat kendisi söyler. Anlatıcının "iyi, usta” gibi artısı olan, olumlu kelimeleri kullanmasıyla birlikte Serhenas'ı anlatıcının ağzından dinleyen okurun aklında olumsuz bir imaj belirmez. Yani okur, roman kişisini bizzat anlatıcının anlatımıyla tanır. Aynı şekilde,

Sıra sıra dizilmiş kagemushaları arasında babasını tanıma sınavlarına çekildiği çocukluk günlerinden beri hiç terlemeyen, bunca yıldır zehrini içinden atamayan Agabu'nun terbezlerinin kilidi sonunda açılmış, yıllardır terleyemediklerinin hepsini birden terlemiş; tenini, yatağını, odasını, evini su basmıştı! Şimdi kendinde olmayan bedeninde sahipsiz kalmış korkuları, yıllardır içinden atamadığı koyulaşmış bir zehrin içinde başıboş yüzüyordu. (s. 285)

sözleriyle Agabu'nun korkusundan bahseden yazar, roman kişisinin endişesini kendi cümleleriyle aktarır.

Olay örgüsünün ya da kişilerin anlatıcı aracılığıyla verildiği ve aktarıldığı anlatma yönteminde okurun dikkati daha çok anlatıcı üzerinde yoğunlaşır. Dolayısıyla bu yöntemin kullanıldığı kısımlarda okuyucu, yol göstericinin aktardığı ve yorumladığı olay ve kişileri dinler. 


\section{Zehra YAZBAHAR, “Murathan Mungan'ın Şairin Romanı İsimli Eserinin Yapısalcı Metodoloji Çerçevesinde İncelenmesi”, Mavi Atlas, 7(2)/2019: 28-53}

\section{Gösterme Yöntemi (Mimesis)}

Murathan Mungan anlatma tekniğiyle birlikte zaman zaman gösterme tekniğine de başvurur ve böylelikle okuyucunun roman kişileriyle aracısız olarak yüzleşmesinin yolunu açar. Gösterme yönteminin kullanıldı̆̆ kısımlarda olay örgüsüne ya da kişilere müdahale en alt seviyededir. Anlatıcının açık tavrının dışında anlatılanın ön planda olduğu bu yöntemde, okuyucunun dikkati metin üzerindedir: “ 'Ne tuhaf,' diye iç çekti Zeey. 'Nedir tuhaf olan?' dedi Tagan. 'Ben de tıpkı senin gibi o günden sonra bir daha uykumda hiç konuşmamışım. Yakalanmamla birlikte benzersizliğim de ortadan kalkmıştı.' ” (s. 63). Zeey ve Tagan'ın karşılıklı konuşmalarına yer verilen alıntıda Mungan; bahsi geçen kişilerin aracı olmadan, kendi ağızlarından tanınmalarının yolunu açar. Yani gösterme veya dramatik yöntemin kullanıldığı alıntıda Zeey ve Tagan, düşünce ve duygularıyla kendi kendilerini ortaya koyarlar. Okuyucu; Zeey ve Tagan'ın hayatından kesitlerin verildiği kısmı, onlardan dinler. Olayları yavaşlatan ve olay ya da kişileri anlatmaktan çok seyrettiren gösterme tekniği, verdiğimiz alıntıda olduğu gibi özellikle diyalogların kullanıldığı kısımlarda ön plandadır. Araya girip sözü keserek müdahalede bulunmayan anlatıcı, devre dışıdır. Kişilerin psikolojik ve sosyolojik durumlarının kendi ağızlarından okuyucuya verildiği bu bölümlerde roman kişileri, kendi kendileriyle baş başadır. Yani kişilerin konuşmaları olduğu gibi sergilenir. Anlatıcı, roman kişilerini ya kendi hâl ve hareketleriyle tanıtır ya da başkalarının onlar hakkındaki düşüncelerini belirterek roman kişileri hakkında ipucu verir.

\section{2. İçerik}

\section{- Konu}

Farklı kişilerin Anakara'da çıktıkları yolculukların paralel bir kurguyla anlatıldığı romanı için "(B)ir dağ gibi, yavaş yavaş çıkıyorsun ve birden bire iniyorsun. Yavaşlık, hız, doğu felsefeleri, yolculuk, kimlik değiştirme, bir esrarın peşine düşme. İçinde bugüne kadar geçtiğim bütün yerlerden, yurtlardan esintiler, izler taşıyan bir roman.” (Arman 2011) diyen Murathan Mungan, romanında şairlerin hayatı şiirle anlamlandırma ve bu yolculuklarında kendi benliklerine ulaşmalarına değinir. Şairleri hedef alarak öldüren bir katilin yolculuğuna da yer veren sanatkâr, bununla hem fantastik edebiyat ile polisiye romanı birleştirir hem de şiirin öldüğü ya da ölmekte olduğu yaklaşımına gönderme yapar. Öyle ki Cem Erciyes'le yaptığı röportajda şiirin sadece insanların zayıf anlarında, âşık olduklarında ya da marazi zamanlarında sığındıkları bir sanat değil, düpedüz varoluşun parçası olduğunu hatırlatarak romanını şiirin ölmekte olduğu söylentisini ironik bir dille eleştirmek amacıyla da yazdığını ifade eder (Erciyes 2011). 


\section{Zehra YAZBAHAR, "Murathan Mungan'ın Şairin Romanı İsimli Eserinin Yapısalcı Metodoloji Çerçevesinde İncelenmesi”, Mavi Atlas, 7(2)/2019: 28-53}

Şairin Romanı'nı yolculuk üzerine kuran ve romanında Cervantes'in Don Quijote'sinden başlayarak roman sanatının çeşitli evrenlerinden izler ile fantastik edebiyat ya da polisiye gibi modern türlerin izdüşümlerinin olduğunu söyleyen Mungan (Börekçi 2013),

Bu kitap sadece bir edebi tür olan şiirden söz etmiyor elbet, öncelikle hayatın şiirinden, tabiatın şiirinden, varoluşun şiirinden söz ediyor. Aslında her hayat bir sanat eseri olmalıdır. İnsanın kendine düşman bir yanı vardır. Öncelikle yenmemiz gereken içimizdeki o gölgedir. Şiire açılan kapısını kendi yüzüne kapatanlar, kendilerinin değil gölgelerinin hayatını yaşayanlardır, yani düşmanlarının. (Aktuğ 2011)

sözleriyle insanların öncelikle içinde var ettikleri düşman yanı yenmeleri gerektiğini ve içlerindeki gölgelerin hayatlarını yaşamaktan uzaklaşarak hayatlarını şiirleştirmeleri gerektiğini anlatır.

\section{- Zaman}

Paralel giden ve iç içe geçmiş zamanları kullanarak roman kurgusunu oluşturan Mungan'ın romanında zaman; nesnel, vaka ve anlatma zamanı olmak üzere üç şekilde ilerler. Diğer bir ifadeyle romanda zamanın kesin bir biçimde belirtilmediği dış zaman dilimi yani nesnel zamandan; bu nesnel zamanın bazı saatlerinde, günlerinde, aylarında ya da yıllarında geçen olayların anlatıldığı zaman yani vaka zamanından ve romanın yazıldığı zaman yani anlatma zamanından bahsedilebilir.

\section{Nesnel Zaman}

Takvime bağlı ya da somut zaman da denilen nesnel zaman, romanın dışında var olan kişilerin de paylaştığı ortak zaman dilimidir. Usta şair Bendag'ın şiiri bıraktıktan elli yıl sonra Anakara'ya dönmesinin anlatılmasıyla başlayan romanın nesnel zamanını -tam belirtilmese de- yaklaşık yüz yıl olarak verebiliriz. Kesin olarak hangi yıllarda geçtiği bilinmeyen romanda okuyucu, olayların hangi zaman aralığında geçtiği ya da roman kişilerinin hangi zaman aralığında yaşadığını öğrenemez. Diyebiliriz ki romanında ütopik bir dünya yaratarak hayalindeki mekânı oluşturan Mungan, olayları da yine kendi var ettiği bir zaman diliminde verir.

\section{Vaka Zamanı}

Romanda sözünü ettiğimiz yüz yıllık nesnel zamanın bütünü kullanılmaz. Olayların geçtiği zaman olan vaka zamanı, nesnel zaman içinde seçilen zaman dilimleridir. Böylelikle Mungan; romanında yer alan hadiseleri ya da kişileri bütün 
ayrıntılarıyla değil, ana hatlarıyla sergiler. Gereksiz ayrıntılar verilmeyerek atlanır ve nesnel zamanın tamamından ziyade sadece olayların geçtiği zaman dilimlerinden bahsedilir. Roman kişileri, akıp giden nesnel zamanın belirli anlarında karşımıza çıkar.

Nesnel zamanda geçen olayların vaka zamanında özetlenerek ve daraltılarak sunulması, okuyucunun ana konuya odaklanmasına yardımcı olur. Öyle ki şimdiki zamana 1şık tutmak amaciyla roman kişilerinin geçmişlerini ve içinde bulunulan hâli, özetleme tekniğini kullanarak okura sunan Mungan; olayları ya da kişileri genel özellikleriyle tanıtır. Bu sayede okuyucu, bir bütün olarak roman kurgusunun içinde yer alır. Bununla birlikte geriye dönüşlerle nesnel zamandan geriye gidilerek önceki zamanlarda meydana gelen bazı olaylar verilir. Romanda geçmiş ve şimdinin içine alındığı tek bir zaman kurgulanır. Şimdiden bahsederken geçmişin bazı anlarına giderek romandaki olay halkalarını birbirine bağlayan sanatkâr, olay örgüsünü oluşturur.

\section{Anlatma Zamanı}

Romanda geçen hadiselerin okuyucuya sunulduğu, diğer bir ifadeyle romanın yazıldığı zaman olan anlatma zamanı; anında aktarma ve sonradan aktarma yöntemleriyle gerçekleşir. Yani romanda bahsi geçen olay ya da kişiler, sıcağı sıcağına aktarıldığı gibi olup bittikten sonra da aktarılır. Bilge şair Bendag'ın elli yıl sonra hayatının son günlerini geçirmek için doğup büyüdüğü toprak olan Anakara'ya geri dönmesi ve geri dönmesiyle birlikte yaşanan hadiselere yer verilen kısımlarda anında aktarma tekniği kullanılır. Ancak romanda içinde bulunulan zamanla paralel olarak elli yıl önce, Bendag'ın Anakara'y1 terk etmesiyle denk zamanda meydana gelen bir olaydan da bahsedilir: Usta şair Moottah ile çırakları Zeey ve Tagan'ın hikâyesi. Moottah, Zeey ve Tagan'ın hikâyesinin anlatıldığı bölümlerde ise sonradan aktarma söz konusudur. Elli yıl önce yaşanan bu olay, anında aktarılan zamanda yaşananlarla paralel verilerek zengin bir anlatıma imza atılır.

\section{- Mekân}

Murathan Mungan'ın anlatımıyla kâinattan, dolayısıyla tabiattan kopan insana bu kopuşun ya da yabancılaşmanın bedelini ve hıza, gürültüye, yağmaya, yıkıma, sürekli bir yarışa emanet edilmiş hayatın içindeki gerçek kaybını hatırlatan Şairin Romanı, okuyucuya şiirden beslenen bir dünyanın -Anakara'nın- kapılarını açar. Romanda anlatılan ülke olan Anakara ile gerçekte yaşanılan dünya arasında oldukça büyük bir fark vardır. Romanında bilinen, görülen, içinde yaşanılan bu dünyaya ait somut mekâna yer vermek yerine soyut planda kalan, hayalî, ütopik bir mekâna yer veren Mungan, mekân olarak ideal mutluluk diyarı olarak sunduğu Anakara'yı yaratır: 
Açık denizde dev dalgalarla boğuştukları aylarca süren firtınalı deniz yolculuğunun sonunda o sabah, Anakara'nın güneybatı körfezine özgü yumuşak rüzgârın o tanıdık kokusuyla uyandı. Kendine özgü bu sakız kokusuyla birlikte Bendag'ın kendisinden önce gömülü anılarını uyandırdı körfez rüzgâr1; belleğinin kuytu derinliklerini uyandırdı. Güneybatı körfezinin sezdirmeden insanın içine işleyen meltemiydi bu. Bunca yıl başka hiçbir denizde, hiçbir körfezde karşılaşmadığ 1 ve ne zamandır unutmuş olduğu belli belirsiz denebilecek bu incecik kokuyu, döndüğünde onu karşılayacak şeyler arasında saymak aklına bile gelmemişti. (...) Güneş ufuk çizgisinde uçuk kızıllığıyla kendini göstermeye başlamıştı. Denize vuran incecik altın teller kopkoyu bir lacivertliğin üzerinde kılcal çakımlarla titreşip duruyordu. Yelkenlerini dolduran cömert ve hafif rüzgârla körfezin durgun denizini yararak ilerliyordu kadırgaları; açık denizdeki nice firtınaya bu sert mizacıyla dayanan kadırgaları... (s. 9).

Mungan'ın hayalinde özel olarak üretilmiş olan Anakara, insan ruhunun özlemlerini karşılayan ideal bir ülkedir ve olaylar, ütopik bir kara parçası olan bu yerde geçer. Anakara, çoğunluğunu şairlerin oluşturduğu roman kişilerinin iç dünyalarını aydınlatmada ve kişiliklerini belirlemede önem kazanarak olay örgüsüyle kişilere yardımc1, adeta canlı ve hareketli bir unsur olarak sunulur.

Okuyucuya ütopik ve fantastik özellikleriyle aktarılan, kahvehanelerinde şiir toplantıları yapılan, şehirlerinde şiir festivalleri düzenlenen, şehir kalelerinin burçlarına şiir bayrakları asılan, şehirleri şiir aracılığıyla tanıtılan ve içinde uyku hanlarını, rüya havuzlarını, büyü ormanlarını, şiir okuyan kuyuları, on üç dolunaylı gökyüzünü barındıran Anakara; mitsel dönemi andıran bir ülke olarak kurgulanmıştır. Şiirin bütün güzellikleriyle donatıldığı Anakara'da bununla birlikte cinayet ve kıskançlık gibi duygular da yer alır. Yani yazar, iyinin yanında kötülüklere de yer vererek fantastik bir metin ortaya koyar. Aynı zamanda okuyucuyu; Kızıldereli, Selçuklu, Alevi, İslâm ve Hristiyanlık kültürlerinin bir senteziyle selamlayan sanatkâr, "Künt kapıları anlatırken Moottah, bilenler aslında onun bir Selçuklu mimari geleneği olduğunu anlarlar, ya da ağaç kesme törenlerini Tahtacıları ve Alevi geleneklerini bilenler anlarlar. ${ }^{3}$ Kagemusha'da sinemasal anlamda esinlenmeler vardır, ne bileyim Italo Calvino'nun

\footnotetext{
3 Tahtacılar; geçimlerini ağaç kesip dilmek, kiriş ve tahta biçmekle sağlayan, Anadolu'da genellikle ormanlık alanlarda, orman işçiliğinin yapılabildiği bölgelerde yaşamlarını sürdürmüş Alevi-Türkmen zümrelerinden birisidir. Tahtacılarda ağaç kesimine başlamak büyük önem arz etmektedir. Ormanda ağaç kesimine başlanmadan önce herkes temizlenir ve yeni elbiseler giyilir. Ağaç kesiminin yapılacağı ormanda, işe başlamadan kurban kesilmesinin zorunlu olduğuna inanılır. Bunun için oradaki aileler ortak bir hayvan alarak "pay kurbanı" denilen hayvanı kurban ederler. Kurbandan yapılan yemekler, topluca yenilir. Ağaç kesimine ancak yapılan törenden sonra başlanabilir. Ağaç kesimini çeşitli dinî/inançsal ritüeller eşliğinde gerçekleştiren Tahtacılar, geçimlerinin önemli bir bölümü için muhtaç oldukları ağaçları kesmeden önce tören yapıp kurban keserek ağacın rızasını aldıklarına inanırlar.

Bakınız: Kocadayı 2013: 58-68, Tamay 2009: 3-6.
} 
'Görünmez Kentler'i de beni kışkırtmıştır. Yani çeşitli metin içi göndermeler var burada.” (Erciyes, 2011) diyerek romanda birçok kültürün izlerini görmenin mümkün olduğunu ifade eder.

Batının fantastik roman geleneğindekine benzer anlayışla bir gezegen kurup başka bir âlemi anlatan Murathan Mungan; bahsini ettiği romanlarda yer alan kralların, kraliçelerin, prenslerin ya da cengâverlerin yerine kendi romanının sol hülyaları ve sol değerleri olan bir yazarın ütopyası olduğunu belirtir. Zira romanında kurum ve kavramları önemseyen, kutsayan bir toplum tasarlamaz. Aksine kurduğu dünyada Firdevsi'nin Şehnamesi'ni, Sadi'nin Bostan'1nı, Mevlana'yı, Konfüçyüs'ü okumuş biri olarak karşımıza çıkar. Tabiata değer verilen ütopik bir mekân olan Anakara'yı yaratarak insanların günümüzde tabiattan ne kadar uzaklaştığını ve nasıl bir hayat sürdüklerini idrak etmelerini ister (Börekçi 2013). İnsana, doğaya, emeğe saygının olduğu, kadına değer verildiği ve teknolojik gelişmelerden uzak bir yer olan Anakara, şiirle doğanın/tabiatın buluşmasının ürünüdür. ${ }^{4}$

\section{- Şahıs Kadrosu}

Olay örgüsü Anakara'da geçen romanda, kişilerin çoğu şairdir ya da şiirle ilgilenen kişilerdir. Romanda elli yıl önce terk ettiği Anakara’ya dönen bilge şair Bendag; Bendag'ın Anakara'dan gittiği vakit öldürülen şiir filozofu Moottah ile çırakları Zeey ve Tagan; atlı polis Gamenn; yarı mecnun, yarı kâhin, yarı şair Ümma; rüya terbiyecileri; şiir okuyucular; sözlükçüler ve yolu şiirle kesişen daha birçok kişiyle hayal şöleni yaratılır. Aynı zamanda bu kişilerin çoğu yüzü geçkin yaşlarıyla dikkat çeker. Roman kişilerinin bu kadar yaşlı kişiler olmasının özel bir sebebi olmadığını belirten Mungan,

(...) hayat, bize bir gençlik projesi olarak öğretiliyor. Hep bir gençlik tapınmacalığı var. Genç kadın olmak, güzel kadın olmak, yakışıklı adam olmak... Hepimiz bunun tuzağına düşüyoruz. 'Yaşına göre giyinmeyen kadın' denir ya da 'O yaşta adam bunu yapar mı?' Böyle bir kültürün içinden geliyoruz. Oysa yaşl11lkta, edindiğimiz zenginliklerin esamesi okunmaz. (Arman 2011)

\footnotetext{
${ }^{4}$ İlk defa Thomas More'un Bir Ulusun En İyi Devleti ve Yeni Utopia Adası Üzerine isimli eserinde ortaya çıkan ütopya kavramı, "olmayan ya da bulunmayan yer" anlamına gelir. Temel özellikleri "hayali olma" ve "ideallik" olan ütopyayı ideallik özelliği dışarıda bırakılarak "şu anda var olmayan, hayali toplum, devlet, yer ya da dönem" olarak düşünmek mümkünse de ideallik, ütopyanın genellikle kabul edilen bir özelliğidir. Dolayısıyla Şairin Romanı'nda cinayetin veya diğer kötülüklerin olması bu eserin ütopik olmasına engel olmasa da ütopyanın ideallik özelliğine uymaz.

Ütopya ile ilgili ayrıntılı bilgi için bakınız: Omay 2009.
} 


\section{Zehra YAZBAHAR, "Murathan Mungan'ın Şairin Romanı İsimli Eserinin Yapısalcı Metodoloji Çerçevesinde İncelenmesi”, Mavi Atlas, 7(2)/2019: 28-53}

diyerek romanda yaşlılığa övgü yapıldığını, Eski Yunan'da, Anadolu'daki bazı İslâm tarikatlarında ve doğu bilgeliğinde yaşlılığın erdemleri olduğunu ifade eder.

Romanda bahsi geçen kişiler ve kişilerin özellikleri şu şekilde verilebilir:

Bilge Şair Bendag: Elli yıl önce doğup büyüdüğü topraklara -Anakara’ya- veda ederek ortadan kaybolan ve Anakara' da yaşayan insanlar tarafından öldüğü sanılan, ünü okyanuslar ötesine ulaşmış bir şairdir. Elli yıl boyunca Yerküre'yi dolaşan Bendag, elli yaşında terk ettiği Anakara'ya yüz yaşında geri döner ve ömrünün son zamanlarını burada geçirmek ister.

Şiir Filozofu Moottah: Evinden çıkmayarak kitaplara gömülmüş bir vaziyette yaşayan Moottah; yaşamı boyunca bilginin ve erdemin peşine düşmüş, güzelliğe değer veren, ondan tat almayı bilen biri olarak yüksek duvarlar arasında saf bir yaşantı yaratmak isteyen şiir filozofudur. Cadebra'daki evinde geçirdiği yirmi yıllık okuma ve düşünme inzivasından sonra yanına aldığı çırakları Zeey ve Tagan'la birlikte Anakara'yı baştanbaşa dolaşıp gittiği yerlerde şiir ile hayat üzerine dersler vermek ister. Ancak arkadaşı Serhenas'1 öldürerek onun şiirlerini çalan Agabu'yla yollarının kesişmesiyle hayatı değişir. Agabu'nun karısı Zeheyra'nın bu gerçeği öğrenip Moottah'a anlatması ve gerçeği Odragend'deki On Üç Dolunaylı Yıl Şenlikleri'nde açıklamasını istemesiyle şiir filozofu, arkadaşı Serhenas'ın uğradığı haksız durumu bozarak arkadaşına ait haklı ünü vermek isterken çırakları Zeey ve Tagan ile birlikte gerçeğin ortaya çıkmamasını isteyen Agabu tarafından öldürülür.

Gamenn: Anakara'nın zeki ve tanınmış atlı polisidir. Tagan'ın ikiz kardeşidir. Sık sık Ümma ile dertleşen, ona fal açtıran ve gördüğü rüyaları yorumlatan Gamenn, Anakara'nın bir süredir meşgul olduğu şair katilini yakalamak için çalışır. Rüyalarında katili ve işlediği cinayetleri gören atlı polis, gördüğü bu rüyaları Ümma’ya anlatarak rahatlamaya çalışır. Yalnızlığı severek her zaman yalnızlığını her şeyin üstünde tutar ve yalnızlığın öğrettiklerinin insanların öğrettiklerinden fazla olduğuna inanır. Hayatta hiçbir konuda fazla yük almak istemez ve çocukluğundan bu yana ilgi alanı "bilinmezler" olur. Anakara'nın en meşhur ve en gözde atlı polisi, öldürüldügünü düşündügü ikiz kardeşi Tagan'la birlikte bütün çocukluğundan ve babalık hakkından vazgeçer.

Zeey ve Tagan: Günden güne tek bir bedenmiş gibi davranmaya başlayan bu ikiz kardeşlerin ikizlikleri kendileri için tehlikeli, başkaları için korkutucu bir hâl almaya başlayınca aileleri kaygılanarak onları birbirinden ayırmaya karar verir. Böylelikle Moottah ile yolları kesişen bu ikizler, Moottah tarafından çırak olarak alınırlar fakat şiir filozofuyla birlikte öldürülürler. Öldü bilinen Tagan, elli yıl sonra hafızasını kaybetmiş 


\section{Zehra YAZBAHAR, "Murathan Mungan'ın Şairin Romanı İsimli Eserinin Yapısalcı Metodoloji Çerçevesinde İncelenmesi”, Mavi Atlas, 7(2)/2019: 28-53}

şair katili olarak karşımıza çıkar ve ikiz kardeşi Gamenn tarafından yakalanır. Ustası Moottah'1n ölmeden önce ona emanet ettiği, bütün gerçeklerin saklı olduğu çantayı yıllarca koruyan ve hafızasını kaybettiği için meczup bir şekilde yaşamını sürdüren Tagan, Gamenn'le karşılaştığında çantayı teslim etmenin huzuruyla kendini boşluğa bırakarak ölür.

Serhenas: Moottah'ın tutkulu ve ateşli olarak tarif ettiği şair arkadaşıdır. Şair olup olmayacağını bir an önce öğrenmek isteyen Serhenas, zamanı aşmış ve bir şeylere bir an önce karar vermesi gerekiyormuş gibi yaşar. Şiirlerini çok beğenen ve onlara sahip olmak isteyen Agabu tarafindan öldürülür.

Agabu: Serhenas'1 öldürerek onun şiir defterine ve şiirlerine el koyar. Böylelikle Anakara'da ünlü bir şair olur. Serhenas'ın arkadaşı Moottah'a ithaf ettiği “Gölgelerin Dili” isimli şiiri, evlendiği gün Zeheyra'ya hediye ederek karısının ona hayran kalmasını sağlar. Ancak Zeheyra, zaman geçtikçe ve Agabu'nun elindeki Serhenas'a ait şiirler tükendikçe kocasının şairliğine yönelik bilinmeyen bir giz olduğunu anlar. Kocasının kendisini Avona isimli genç bir kadınla aldattığını öğrenince intikam duygusuyla kocasının şiirleri kimden aldığını bulmaya çalışır. Sonunda Serhenas'ın şiir defterine ulaşan ve bu şiirlerin Serhenas tarafından yazıldığını öğrenen Zeheyra, Agabu'nun yıllarca sakladığı bu gerçeği ortaya çıkarmak isterken Agabu tarafından öldürülür.

Zeheyra: Oldukça güzel, gösterişli, çekici bir kadın olan Zeheyra, Agabu'nun eşidir ve varlıklı bir ailenin kızıdır. İnsanlar üzerinde olumlu bir etki bırakır. Şiir yazamayacağını anladığından kendisini şiir okuyucusu olarak yetiştirir ve toplantılarda aranan bir şiir okuyucusu olur. Yirmi bin şiiri ezberinde tutar.

Avona: Agabu'nun ikinci eşidir. Fiziksel olarak şaşırtıcı bir şekilde Zeheyra'ya benzemesine rağmen Zeheyra'nın coşkusu ve çekiciliğinden yoksundur. Büyüyle uğraşan ve her daim genç görünen kadın; mesafeli, soğuk ve gizemlidir. Bu yüzden Agabu, hiçbir zaman Avona'nın hislerini ve düşüncelerini anlayamaz.

Ümma ve Lelalu: Anakara'nın en meşhur kadın şairleridir. Yarı mecnun, yarı kâhin, yarı şair olarak tarif edilen Ümma'nın kehanetlerinin ve gördüğü rüyaların çoğu doğru çıkar. Hisleri kuvvetli olduğundan insanlar onun kehanetlerine inanarak ona sayg1 duyarlar. Ancak kehanetlerinin doğruluğu hayatta ve kaderde süreklilik göstermez. Diğer kâhinler ve büyücüler bu durumu Ümma'nın aynı zamanda şair olmasına bağlarlar ve şairliğinin gücünü, kudretini böldüğünü, hükmettiği âlemleri birbirine karıştırdığını, birinin kapısından diğerine geçerken bazı güçlerin ardında kaldığını düşünürler. Öyle ki onlara göre şairlik, erkek işidir ve Ümma, erkeklerin işini yapmaktadır. 


\section{Zehra YAZBAHAR, "Murathan Mungan'ın Şairin Romanı İsimli Eserinin Yapısalcı Metodoloji Çerçevesinde İncelenmesi”, Mavi Atlas, 7(2)/2019: 28-53}

Okuma yazma bilmeyen Ümma, şiirlerini içe doğuş hâlinde söyler ve diğer kadınlar şiirleri yüksek sesle tekrar ederek ezberlerine alırlar. Bir zaman sonra bazı şiirlerini beğenmeyerek şiirlerini ezberleyen kadınlardan onları unutmalarını ister ve onun unutun demesiyle kadınlar kendiliğinden Ümma'nın beğenmediği şiirlerini unuturlar. Kalmasını ve yaşayıp söylenmesini istediği şiirleri ise yaşar, söylenir ve daha sonra bazı kadın yazıcılar tarafından kaleme alınarak saklanır. Gözleri pek iyi görmeyen, herhangi bir insan yüzüyle karşılaştırıldığında iki gözü arasındaki mesafe fazla olan, gözlerini belli bir noktada odaklamakta güçlük çeken Ümma, on bin şiiri ezbere bilir.

Anakara'nın Micla şehrinde yaşayan Lelalu da Ümma gibi takdir edilen bir şairdir. Birbirlerini şiirlerinden tanıyan bu iki kadın, birbirlerine takdir ifadesi olarak hediyeler yollarlar. Becerikli, kibar ve güzel olan Lelalu'nun yaşı ilerlemesine rağmen güzelliğinde bir değişim olmaz. Babasının posta güvercini yetiştirme merakından dolayı Anakara'nın farklı şehirlerinde güvercin çiftliklerinde büyüyen Lelalu, evinin bahçesinde güvercin besler. Şairliğinin ilk yıllarında yazdığı şiirleri posta güvercinleriyle Anakara'nın dört bir yanına yollayarak şiirlerinin ve kendinin tanınmasını sağlar. Ayrıca Lelalu, eşcinsel olmasıyla dikkat çeker.

Dohanaralı Sözlükçü Tarkusyu: Büyük bir aşkla bağlanıp evlendiği karısının erken yaşta gelen ölümünden sonra ne yapacağını bilemeden dolandığı çaresiz günlerinde acısını dindirmek ve ruhunu sakinleştirmek amacıyla sözcük aramaya başlayan ünlü sözlükçüdür. Yeni sözcükler bulmanın da bir tür şairlik olduğuna inanan Tarkusyu; bu uğurda bütün Anakara’yı köy köy, kasaba kasaba, şehir şehir gezerek dillenmemiş yeni sözcükler bulmak için çabalar. Oğluyla birlikte yaşar ve oğlunun da kendi gibi sözlükçü olmasinı ister.

Vylea: Çekici, güzel, sezgileri güçlü, hazırcevap bir kadın olan Vylea, Lelalu'nun eski sevgilisidir. Kırmızı Kent’te yaşar ve çocuk yaşam evinde çalışır. Lelalu'ya karşı hayranlık besleyen Gamenn tarafından kıskanılır.

Ulsangeyma: Bendag'ın Anakara'ya döndüğünde tanıştığı ilk kişidir. Keçe işçiliğinde çalışmasına rağmen şiire karşı meraklı olan kadın, iyi bir şiir okuyucusudur. Her ne kadar kimliğini saklamaya çalışsa da Bendag'ı tanıyan Ulsangeyma, zeki ve görgülüdür. Hem Bendag'ın kimliğini saklamasına hem de polis kontrolünde tanıklık ederek Bendag'a yardım eder.

Dehamar: Yeni şiirlerini insanlara tanıtmak amacıyla Anakara' da yapılacak olan On Üç Dolunaylı Yıl Şenlikleri’ne doğru yol alan şairlerden biridir. Şairleri öldüren katil 


\section{Zehra YAZBAHAR, "Murathan Mungan'ın Şairin Romanı İsimli Eserinin Yapısalcı Metodoloji Çerçevesinde İncelenmesi”, Mavi Atlas, 7(2)/2019: 28-53}

tarafından Makrakamash’ta ağır bir saldırıya uğrar ve katilin saldırılarından kurtulabilen tek şair olarak anılır.

Terzi Liuv: Anakara'nın Udbera şehrinde yaşar. Moottah'ın yolculuğu sırasında onu ve çıraklarını evinde ağırlar. Yıllarca Anakara'nın çeşitli bölgelerinde yaşayıp birbirinden farklı işlerde çalıştıktan sonra Udbera'ya yerleşmeye karar veren Liuv, kendisini şair olarak yetiştirmek için yıllarca uğraşıp onca emek verdikten sonra her şeyi birakarak terzi olur.

Haritacı Kaa, Horad ve Bilgin Qkhanyus: Kaa, Anakara'yı avucunun içi kadar iyi bilen haritacıdır. Haritalarda kimsenin göremediği yerleri keşfeder. Dilsiz olduğundan yüzünün hareketli çizgilerini fazlaca kullanan Horad, yerküreyi katman katman okuyan gözlere sahiptir. Qkhanyus, Gamenn'in hınzır zekâlı olarak tarif ettiği ünlü sayıbilim bilginidir. Bahsi geçen her üç kişi de özel yeteneklerle donatılmış, seçilmiş insanlardır ve yetenekleriyle kazandıkları başarılar sayesinde ünleri Anakara'nın dört bir yanına dağılır.

Pepqemok: Gamenn'in kabullenmekte zorlandığı yardımcısıdır. Kohragandt Güvenlik Merkezi'nin yanına yardımcı olarak verdiği atlı polis, Gamenn tarafından daha çok güz sonu şenliklerindeki soytarılara ya da Dimoned hasat oyunlarındaki güldürücü tiplere benzetilir. Dolayısıyla tanıştıkları ilk gün ondan hoşlanmaz ve kendini sevdirme stratejisi olarak benimsediği göze girme gayretlerini yapmacık bularak yardımcısını benimseyemez.

\section{Olay Örgüsü ve Vaka Takdimi}

“Şairin Dönüşü”, “Şairin Toprağı”, “Şairin Levhaları”, "Şairin Gölgesi”, “Şairin Hayvanı", "Şairin Kanı" ve "Şairin Oyunu” olmak üzere toplam yedi ana bölümden oluşan romanın her bölümünün kendi alt başlıkları vardır. Mungan, şairle alakalı olan bu bölüm isimlerini "Şairin Romanı” başlığında toplayarak kendi emek sürecine de gönderme yapar. Romanını on dört yılda oluşturduğu ve 1992'de yayımladığı tiyatro oyunu Geyikler Lanetler'e benzeten sanatkâr, romanının hem kurgusal anlamda farklı bir fantezi hem de farklı bir metin olduğunu da sözlerine ekler. Bununla birlikte kitabını roman kişilerinden Ümma gibi rüyalarıyla, çağrılarıyla, görüleriyle yani şaman tarafiyla ve Türk edebiyatıyla Dünya edebiyatını yakından izleyen biri olarak kuramsal donanımını, entelektüel birikimini kullanarak yazdığını belirterek şaman yanıyla teknisyen yanının birleşmesiyle bu kitabın ortaya çıktığını söyler:

Aslında doğusunun batısının kalmadığı bir dünyada yazı yazıyoruz. Ama kendi topraklarımızın malzemesini kendi hayal hanemize taşıyarak... 'Şairin Romanı' bütün o hayal gücüyle beraber okumalar, yılların içinde biriktirmeler, 
araştırmalarla ortaya çıktı. Çok ciddi bir araştırma, salların ilmeklerinden doğanın ayrıntılarına, çekirdekten fidelere kadar pek çok şey hakkında çok ciddi bir okuma süreci var bu romanın arkasında. (Erciyes, 2011).

Hiçbir coğrafyaya ve zamana ait olmayan fantezi bir dünya kuran Mungan, Binbir Gece Masalları'ndan süzülüp gelen anlatı geleneğ ${ }^{5}{ }^{5}$ ile dünya edebiyatının vazgeçilmezi fantezi romanlarını harmanlayarak kendi gezegenini yaratır. Özellikle üç ana karakterin Bendag, Moottah, Gamenn- yolculuklarının ele alındığı roman, paralel kurguyla ilerleyerek bir noktada birleşen hikâyelerden oluşur. Bilge şair Bendag, gönüllü sürgününden elli yıl sonra memleketi Anakara'ya dönerek son yolculuğuna çıkar. Şiir filozofu Moottah, yirmi yıllık inzivasına son vererek çırakları Tagan ve Zeey ile birlikte ülkeyi gezer. Atlı polis Gamenn ise ülkenin kâbusu olan şair cinayetlerini çözmek amacıyla harekete geçerek kendi yolculuğunu başlatmış olur. Bahsini ettiğimiz bu üç karakterin de hedefi, Anakara'nın Odragend şehrindeki On Üç Dolunaylı Yı1 Şenlikleri'ne katılmaktır.

“(H)em Doğu hem de Batı anlatı geleneğinden beslenen, ütopik, fantastik ve polisiye türü olarak adlandırılabilecek kısacası çoğulcu yapısıyla dikkat çeken bir roman olarak yerini belirginleştiren" (İlhan 2013: 565) Şairin Romanı, yüz yaşını aşan Bendag'ın ömrünün son günlerini geçirmek amacıyla doğup büyüdüğü Anakara'ya elli yıl sonra dönüşünün anlatılmasıyla başlar. Şairlerin hayranlıkla ve büyük bir saygıyla bahsettiği Bendag, insanlar tarafından öldü kabul edilir. Ancak Bendag'ın Anakara'ya adım attığ1 ilk günün gecesinde Anakara'nın diğer ucunda, Ajnera'da yaşayan yarı mecnun, yarı kâhin, yarı şair Ümma, Bendag'ın Anakara'ya döndügü rüyasını görüp bunu çevresindeki insanlara duyurur. Memleketine döndüğünün kimse tarafından bilinmesini istemeyen Bendag, gerçek kimliğini gizleyerek Anakara'daki ilk gecesini Uyku Hanı adı verilen bir handa geçirir. Bu handa odasını, sürekli "Roasanayma" diye sayıklayan hasta bir adamla paylaşır. Yarı baygın yatan adama yardım etmeye çalışsa da adam, Bendag'ın orada kaldığı zaman boyunca uyanamaz. Bendag, yarı baygın adamın yatağının altında duran çantasına bakarken birbirinden farklı birçok kimlikle karşılaşır. Anakara' dayken kimliğini belli etmek istemeyen bilge şair, hayatı boyunca hiç yapmadığı bir şeyi yapıp

\footnotetext{
${ }^{5}$ Hikâye, masal, destan, menkıbe ve fikraları bir araya toplayan Binbir Gece Masalları, çerçeve hikâyeler tekniğiyle yazılmış Arapça bir külliyatıtır. Bu eserin çerçeve anlatısını kadınlara güveni kalmayan ve bu yüzden her gün genç bir kızla evlenip ertesi gün o genç kızın boynunu vurduran Semerkant hükümdarı Şahzamân'ın Şehrazâd ile evlenmesi ve 1001 gece sonunda Şehrazâd'ın zekâsı, becerikliliği karşısında duyduğu hayranlığın etkisiyle Şehrazâd'ı öldürmekten vazgeçmesi oluştururken eserin alt anlatılarını ise Şehrazâd'ın ölümden kurtulmak için Şahzamân'a her gece masal anlatması oluşturmaktadır. Binbir Gece Masalları'nda olduğu gibi Şairin Romanı'nda da “olay örgüsü”nde bahsettiğimiz birbiri içine geçen metin halkaları vardır.
} 


\section{Zehra YAZBAHAR, "Murathan Mungan'ın Şairin Romanı İsimli Eserinin Yapısalcı Metodoloji Çerçevesinde İncelenmesi”, Mavi Atlas, 7(2)/2019: 28-53}

oda arkadaşının çantasından üzerinde "Remzganan" yazılı kimliği alır ve On Üç Dolunaylı Yıl Şenlikleri'ne katılmak üzere yola koyulur. Bendag'ın odasını paylaştığı meczubun, şair katili -aslında atlı polis Gamenn'in öldüğü sanılan ikiz kardeşi Taganolduğu romanın sonunda anlaşılacaktır.

Vatanında ölmek ve şiir yolculuğunu tamamlamak üzere Anakara'yı son bir kez dolaşmak isteyen Bendag, Anakara'dan ayrı kaldığı bu elli yıl boyunca hiç şiir yazmaz. Ancak ülkesine döndüğünde şiir yazmaya kaldığı yerden devam eder ve şiirlerini, "Son Yolculuk" adını verdiği defterinde toplar. Romanın ilerleyen bölümlerinde Bendag'ın yolculuğuna ünlü şiir filozofu Moottah'ın yolculuğu da eklenir. Anakara'nın büyük şairlerinden biri olan Moottah, yirmi yıldır evinden çıkmaz ve devamlı kitap okur. Fakat yirmi yıl sonra bu hapis hayatına son vererek çırak olarak aldığı Zeey ve Tagan'la birlikte büyük bir yolculuğa çıkmaya karar verir. Bu yolculukta hem Zeey ve Tagan'ın ruhlarını bulmasına yardımcı olmaya çalışır hem de gittiği yerlerde insanlara şiirle alakalı bilgiler verir. Moottah'ın eğittiği Zeey ve Tagan, şiir filozofundan hayata ve şiire dair birçok şey öğrenirler. Moottah, Zeey ve Tagan'ın hayat1, Agabu'nun karısı Zeheyra'dan öğrendikleri gerçekle değişir. Öyle ki Moottah, yolculuğu esnasında arkadaşı Serhenas'ın şiirlerini çalıp onu öldüren ve arkadaşının şiirleri sayesinde büyük bir üne kavuşan Agabu'nun bu gaddarlığını Zeheyra'dan öğrenir. Zeheyra'nın kendisine verdiği arkadaşının şiir defterinin ve gerçeklerin yazılı olduğu mektubun bulunduğu çantayla gerçekleri açıklamak üzere On Üç Dolunaylı Yıl Şenlikleri’ne katılmak üzere yola koyulur. Durumu öğrenen Agabu, adamlarını şiir filozofunun peşinden gönderir. Moottah ve Zeey, Agabu'nun adamları tarafından acımasız bir şekilde öldürülürken Tagan da çantayla birlikte kendini uçurumdan aşağı atarak adamlardan kurtulmaya çalışır. Parçalanan cesetlerden üçünün de ölmüş olduğu sonucuna varılsa da Tagan, kör bir adam tarafindan bulunarak kurtarılır. Yaşadıklarından dolayı hafızasını kaybeden Tagan, uğradığı saldırı sonucu akli dengesini yitirerek kendisine saldıran adamlar gibi acımasız olur ve şairleri öldüren bir katile dönüşür. Agabu ise Serhenas’tan çaldığı şiirleri, insanlara kendi şiirleri gibi sunar.

Atlı polis Gamenn'in şair katilini bulmak amacıyla çıktığı yolculuk, romanın üçüncü yolculuğu olarak karşımıza çıkar. Ülkedeki şairlerin öldürülmesiyle ilgili cinayetlerin izini süren Gamenn, yaptığı araştırmalar sonucu katile yaklaşır. Ancak katili yakaladığında onun yıllar önce öldü sandığı ikiz kardeşi Tagan olduğunu görür. Hafizasını yitiren ve bir katile dönüşen Tagan, ustası Moottah'ın kendisine emanet ettiği çantayı Gamenn'e vererek yıllar önce katillerden kaçmak için atladığı uçurumdan elli yıl sonra tekrar atlar. Kardeşini bulduğu an kaybeden Gamenn, kardeşinin bıraktığı çantanın 
gizemini çözmeye çalışır. Çantadan çıkan defterle mektuptan Agabu'nun Serhenas'ın defterini çalıp onu öldürdüğ̈ anlaş1lır.

Murathan Mungan'ın şimdiki zamanla paralel olarak verdiği Moottah'ın şiir yolculuğu, aslında elli yıl önce, Bendag'ın Anakara'yı terk ettiği zamanda başlar. Mungan, geçmişi ve şimdiyi birleştirerek bu üç yolculuğu aynı anda vuku bulan olaylar olarak verir ve okuyucu; bu dügüumü, romanın sonlarına doğru çözer. Elli yıl önce Agabu tarafından acımasız bir şekilde öldürülen Moottah, Zeey ve Tagan'ın öldürülme nedenleri ile Agabu'nun yıllardır sahip olduğu haksız ün, Anakara'ya dönen Bendag tarafından elli yıl sonra Agabu'nun yaşam boyu onur ödülü alacağı o yılki On Üç Dolunaylı Yı1 Şenlikleri'nde ortaya çıkarılır. Böylelikle Mungan; Moottah, Zeey, Tagan, Gamenn ve Bendag'ın hikâyelerini bir noktada birleştirerek elli yıl önce yaşanan acımasız bir cinayetin elli yıl sonra, ülkesine dönen Bendag ve Gamenn tarafından aydınlatılmasını sağlar.

Sonuçta Odragend'deki On Üç Dolunaylı Y1l Şenlikleri'nde, şiirsel bir atmosferde kesişen kahramanların hikâyesi yine 'şiirin adaleti' bağlamında çözümlenir. Bilge Şair Bendag onurlandırılır, Moottah ve çıraklarının heykelleri dikilerek hem şairin çektiği acılar hem de şiirin felsefesi ölümsüzleştirilir. Bu arada Agabu'nun taklitçiliği ifşa edilir ve Agabu öldürülerek bir bakıma onun şahsında taklitçilik cezalandırılır. Böylece şiirsel bir atmosferde cereyan eden anlatı, bu atmosfere uygun bir biçimde sonlanır. (Demir 2013).

\section{4. Şiir Hakkındaki Düşünceler ile Dil ve Üslup}

Adalet ve vicdanın iyilikle ilişkisi üzerine inşa edilen Şairin Romanı'nda, Doğu'nun felsefî gücünü Batı'nın tekniğiyle harmanlayarak veren Murathan Mungan; mistisizm, Antik Yunan metinleri ve tragedyalardan yararlanır. Şiirin insan hayatındaki önemini dile getirerek sanata yakın olduğunu gösteren bir tavır takınıp çoğunluğunu şairlerin oluşturduğu roman kişileri üzerinden şiir ile ilgili görüşlerini yansıtır. Bunu yaparken de roman kişilerine kendilerini şiir aracılığıyla anlatmaları için şans verir. Mungan,

Hayatınızdan şiiri söküp attıysanız, ondan vaçgeçtiyseniz, sadece arızalı zamanlarınızda yardım almak için başvurduğunuz bir yalancı ilâç hâline gelir şiir. Aşıksınızdır, ana baba hasreti çekiyorsunuzdur, gurbette kaybolmuşsunuzdur... Acınızı kışkırtmak yahut yatıştırmak için şiire başvurabilirsiniz o zaman, diğer zamanlarda unutmak üzere... Böyle olunca da, gündelik hayatta şiire duyduğunuz ihtiyacı görmezden gelirsiniz. Şairin Romanı, sadece edebi bir tür olan şiiri değil, yaşamın, varoluşun şiirini de hatırlatmak istiyor okura. (Börekçi 2013) 


\section{Zehra YAZBAHAR, "Murathan Mungan'ın Şairin Romanı İsimli Eserinin Yapısalcı Metodoloji Çerçevesinde İncelenmesi”, Mavi Atlas, 7(2)/2019: 28-53}

sözleriyle şiirin insan hayatındaki önemli yerine değinir.

Türk edebiyatında poetik fikirlerini roman üzerinden vermenin şairlerin pek ilgi göstermedikleri bir yöntem olduğunu ifade eden Fethi Demir, Murathan Mungan'ın Şairin Romanı isimli eserinde Türk edebiyatında ilk kez bir şairin poetikasını yazdığ roman üzerinden açıkladığını belirtir (Demir 2013). Öyle ki romanda, isminden de anlaşılacağı üzere, birçok şiiri olan Mungan'ın şiirle ya da şairlikle alakalı düşünceleri de yer alır. Diğer bir ifadeyle şiir üzerine inşa edilen roman, aynı zamanda Mungan'ın poetikasını da ifşa eder.

Romanın hemen hemen her sayfasında şair roman kişilerince şiir hakkındaki düşüncelere yer verilir. Sık sık ilk ustasını ve onun şiir ya da şairlikle alakalı sözlerini hatırlayan bilge şair Bendag; iyi bir şiirin doğa gibi olduğunu, en çok kullanılan kelimelerle bile şaşırtmayı başardığını düşünür. Yerküredeki her şey, yazılmak için vardır. Tabiatla şiirin birbirini tamamladığını düşünen Bendag için şiir tabiattan, tabiat da şiirden doğar. Ayrıca ona göre şairlerin ortalığa hâkim olacakları saatler, herkesin uykuda olduğu saatlerdir. Çünkü şairler; zaman hırsızıdırlar, başkalarının zamanlarını çalarlar. Yeryüzünün saklı ve uykulu zamanlarını kullanırlar. Şiiri arada bir nöbeti tutan uykudaki hummaya benzeten ve tabiatın öğrencisi olmayanın iyi bir şair olamayacağına inanan Bendag için şiir; kuşanmayı, saklanmayı, sakınmayı, korunmayı, geri çekilmeyi bilen bir iç kale sanatıdır. Kadın şiir okuyucularından Ulsangeyma için ise şiir; onu ilk önce hayata, sonra yalnızlığına ve kayıplarına katlanmaya alıştırarak ona yaşlılığını sevdirir.

Şiirlerinde ham renkleri kullanmaktan korkmayan ve usta bir ressam gibi renkleri 1şı̆̆ın ellerine teslim etmeyi bilen Bendag'ın şairliği hakkında bilgi veren anlatıcı; onun şiirlerinde 1şığın geçişlerini görmenin mümkün olduğunu, bütün şiirlerinde anın ertelenerek zamanın sonsuzlaştırıldığını dile getirir. Şiir, 1şıktan doğar. Şair, bir ressamın dikkatiyle 1şığı kollayandır ve şiiri içinde duymak, yazmak, 1şıkla harfleri buluşturmak için günün çeşitli vakitlerini beklemelidir. Şairlerle ressamlara devlerin dikkati gerekir. Çünkü onlar, görünüşlerinin aksine tabiatın en zayıf canlılarıdır. Bu yüzden daha dikkatli olmalıdırlar ve bir tavşan uykusuyla uyumalıdırlar. Zira hayat, onları her an gafil avlayabilir ve şiirin gökyüzünde tesadüf kuşları uçar. İyi sanat ve iyi şiir, insanı sahip olmadığı zamanlara taşıyarak yalnız geçmişi değil geleceği de haber verir.

Bendag, "Son Yolculuk" ismini verdiği şiirleri yazarken yıllardır bıraktığını sandığı şiirin, içinin tükenmemiş yerlerini harekete geçirdiğini fark eder. Boş sayfaya düşen iki sözcük dahi onu bir anda çocukluğuna götürür. Ona göre şiir ile çocukluk arasında kopması mümkün olmayan bir bağ vardır ve bu ilişki, insanı şair yapar. Şiir 


\section{Zehra YAZBAHAR, "Murathan Mungan'ın Şairin Romanı İsimli Eserinin Yapısalcı Metodoloji Çerçevesinde İncelenmesi”, Mavi Atlas, 7(2)/2019: 28-53}

yazmak için gereksinim duyduğu şey, günışığına yeni çıkmış gibi parıldayan sözcüklere hayat verecek ve yeniden görülmesini sağlayacak olan 1şıktır. Çünkü Bendag için karanlığın şiiri bile 1şıkla yazılır. Şairleri yabani hayvan terbiyecilerine benzeten usta şair, hayvan terbiyecilerinin de hayvanların hem yabani doğalarını koruyup hem de onlara sözlerini geçirdiklerini, kendi şiirleri için hayvanları ehlileştirdiklerini düşünür. İyi şairlerin kanında bilgelikle dizginlemeye çalıştıkları bir hayvan vardır. Çoğu kez şahlandırmakta ya da yatıştırmakta zorluk çektikleri bu hayvan, şairlerin yol göstericileridir.

Çırakları Zeey ve Tagan'la birlikte hayatı anlamlandırma adına bir yolculuğa çıkan şiir filozofu Moottah da Zeey ve Tagan'ı eğitirken şiirle ve şairlikle ilgili düşüncelerini ifade eder. Moottah; şiir ve çömleği birbirine benzeterek her ikisinin de topraktan yapıldığını, sonradan havayla, ateşle, suyla beslendiğini ve sınandığını söyler. Çöken uygarlıklardan geriye sadece yerkürenin en eski tanıkları olan şiir ve çömlek kalır. Şiir de çömlek gibi anayurdun toprağından yapılır, tıpkı onun gibi anakaranın ve yerkürenin her yanında kullanılabilir olmalıdır. Yani ayakları doğduğu topraklara sağlam basarken şair, sözlerini bütün yerküreye söyleyebilmelidir. Bununla birlikte yalnızca kendi toprağında okunulabilir olması iyi şiir için yeterli değildir. İyi şiir, doğduğu toprakların iklimini başka iklimlere dönüştürebilme gücüne ve yeteneğine sahiptir. Kendi güneşini, kendi rüzgârını ve kendi yağmurunu her yere taşıyarak gittiği yerin güneşi, yağmuru, rüzgârı olmalıdır. Moottah'ın şiir ile çömlek benzetmesi, onun düşüncelerine katılan sözlükçü Tarkusyu'ya şiir levhalarını hatırlatır. Zamanında kendi şiirlerini adeta gizli dillere rakip görmeye başlayan Nehanunulu şairler, şiirlerini kil levhalara yazdırdıktan sonra onları toprağa gömerler. Böylece topraktan yani doğadan aldıklarını yine toprağa verdiklerini düşünürler. Moottah'a göre inanışlar, şiirin doğasına hizmet eden kutlu oyunlar olarak kaldıklarında anlam taşırlar. Kıskanç şairler, yazdıklarının yabancı gözler tarafından okunmasını istemeyenler ya da onları bir süre herkesten gizlemek isteyenler görünmez mürekkeple; kuzey denizlerinde yaşayanlar gri mürekkeple; güney denizlerindekiler mavi mürekkeple; kızıl ve yeşil mürekkebin büyüsüne inananlar bu mürekkeplerle yazarlar. Fakat şiirin kanı, mürekkep değildir. Çünkü iyi bir şiir, her çeşit mürekkeple yazılabilir. Mürekkep yalnızca elimizin altındaki doğrulardır. Tabiatın koruyucusu olan şairler, evrensel bellekte yaşayan kişilerdir ve kendi zamanlarına kilitli olanların şairliği yalnızca bir çalışkanlıktan ibarettir. Bu şairlerin verimleri, kısa ömürlüdür. Ne kadar iyi şair olunursa olunsun şiir; herkesin ruhuna, kalbine, aklına dokunmayabilir. Kendilerine ait hayali olmayanlar, şairlerin yazdığ şiirleri göremeyebilirler. Dolayısıyla şiirleri herkes tarafından beğenilmeyen bir şair, 


\section{Zehra YAZBAHAR, "Murathan Mungan'ın Şairin Romanı İsimli Eserinin Yapısalcı Metodoloji Çerçevesinde İncelenmesi”, Mavi Atlas, 7(2)/2019: 28-53}

bütün suçu kendinde bulmamalıdır. Mayası şair olarak doğmuş birinin kelimeleri uzun süre karanlıkta kalmaz. Hiçbir güç, doğuştan gelen bu yeteneği bağlayamaz. Her şiirde sözcüklerin dolduramadığı boşluklar vardır. En kusursuz şiirde dahi var olan bu boşluğu, sadece şairin kendisi bilir ve boşluktan defalarca yeni bir şiir oluşturur. Çünkü boşluğu dolduracak şeyin, başka şiir olduğunu düşünür. Oysa şairler yalnızca birbirlerinin boşluklarını doldururlar.

Üzerlerinde farklı ahşap parçaların geometrik bir düzen içinde yer aldığı bu kabartma kapılara 'Künd Kapılar' denir çocuklar. (...) Artık kullanılmayan ölü bir dilde 'bir işin ustalığı, kurnazlığı' anlamına gelirmiş 'künd' sözü. Sonraları 'kavramak' anlamında da kullanılır olmuş. Ama buğun biz 'künd' denince, şu kapılarda, kepenklerde gördügünüz son derece ustalık, titizlik ve hesap gerektiren bu ahşap bezeme sanatını anlıyoruz. (s. 241)

diyerek künd kapılarını anlatan Moottah, bu kapılarla şiirin benzer olduğunu ifade eder. Şair, kapıları oluşturan parçalar gibi şiiri var eden parçaların da yeniden sökülüp takılarak oluşturulduğuna inanır. Bir yapıyı meydana getiren parça ile bütün ilişkisi, şiirin kendi hakikati içinde tartılmalıdır. Hakiki şairler ile geçmiş mirasın tahtalarından devşirdikleri parçalarla sadece taklit ürünler veren şairleri birbirinden ayırt etmek gerekir. Sanat yapıtlarıyla kapılar arasında böyle künd bir ilişki olduğu unutulmamalıdır. Şairin özgün olmasının gerektiğine değinen Moottah’1 Mungan, simgesel bir mekân olarak yarattığı "Şairin Kuyusu” ile destekler. Şairler, kendilerine ve yazdıkları şiirlere inandıkları zaman kuyuya giderek şiirlerini yüksek sesle okurlar. Eğer kuyu, şiirde şairin kendi sesini bulmuşsa şairin sesiyle yankılanır. Fakat şairin sesinde başka şairlerin sesi duyuluyorsa kuyu, o duyulan şairin sesiyle cevap verir. Görüldüğü gibi özgünlüğe önem veren Mungan, bu düşüncesini roman kişilerini kullanarak dile getirir. Bazı şiirlerin güzelliklerini kusurlarından aldığını da söyleyen Moottah, şiirin söylenenden çok söyleme biçimiyle alakalı olduğunu savunur. Doğaçlanmış sözcüklerin hızı, zamanla şaire bir teknik kazandırır. İyi şairler, ışı̆̆ı gözetlemesini bilmelidirler. Nasıl nesnelere derinliğini veren 1şığın eğilip bükülmesi ise iyi şair de 1şığı tartabilmesini bilendir. Şiir; kendini zorla benimsetmez, kendini açığa vurur. Ayrıca kelimelerin kullanılışında değil, kelimelerle kurulan ilişkide başlayan şiir, hakikat sanatıdır ve şiir için gerçeklerin ortaya çıkmasından daha büyük bir amaç yoktur.

Matematik ve şiiri birbirine benzeten haritacı Kaa ise, şiir sanatındaki ilk büyük yenilikleri getiren şiirleri casusların yazdığını belirtir. Gizlice bilgi ulaştırmak ve haber iletmek için kullanılan ilkel bir dil düzeneği, sonradan şiir sanatının gelişmesini sağlar. Büyük imparatorluklar zamanında casusların haberleşme aracı olarak kullandıkları bu 


\section{Zehra YAZBAHAR, "Murathan Mungan'ın Şairin Romanı İsimli Eserinin Yapısalcı Metodoloji Çerçevesinde İncelenmesi”, Mavi Atlas, 7(2)/2019: 28-53}

şiirler, daha sonra "içrek şiir” diye nitelendirilen kapalı anlamlı şiirlere dönüşürler. Matematik bir gerçekliktir ve şair de tıpkı matematikçi gibi betimsel gerçekliğe bağlı değildir. Şiir, matematiğin evrendeki görünmezliğine ne denli yaklaşabilirse o kadar iyi bir şiir olur.

Şiirden beslenen bir dünyayı anlatmasına rağmen romanda hiç şiire yer vermeyen Mungan, bu durumu "Ancak acemi bir yazar böyle bir romanda, şiirleri örneklemeye kalkardı. Orası okurun hayalhanesinin hakkıdır. Ne yazsanız, ne koysanız olmaz. Bu aynı zamanda romanın dramaturjisinin de gereğidir. Ama her satırının adeta şiir olduğunun söylenmesi hoşuma gidiyor.” (Aktuğ 2011) cümleleriyle açıklar. Şiirle ya da şairlikle ilgili temel görüşlerini belirtmekle yetinen Mungan, görüşlerini destekleyecek şiir örneklerine yer vermeyerek romanın her satırının bir şiir örneği olduğunu kanıtlar.

Roman; ütopik bir şiirsel gezegen ve burada yaşayan, her biri farklı değerlerle donatılan ütopik kişiler üzerine kuruludur. Nail Bezel'e göre, yazarın kurduğu özlem dünyasını çağının anlatım geleneklerine göre dile getirmesi olarak tanımladığı ve pürüzsüz işleyen mutlu düzen şeklinde yaklaştığı ütopik romanda gerekli çatışma, gerilim ve çözümlemeler bulunmaz (Bezel 1989: 2-3). Ancak kişi, mekân ya da zaman seçiminde ütopik ve fantastik unsurlardan yararlanan Mungan, aynı zamanda polisiye romanının getirdiği çatışma, gerilim ve çözümlemeleri de kullanarak romana sürükleyici bir dil ve üslup kazandırır. Yani yazar, gerçekçi edebiyatın geleneklerinden ve sınırlandırmalarından özgür olarak ortaya çıkardığı romanında; ütopyanın zamansızlık ve mekânsızlığını, Tzvetan Todorov'un karmaşayla birlikte gelen kararsızlık olarak ifade ettiği fantastik edebiyatın (Todorov 2004: 31) gerçekle yanılsama ya da düş arasındaki durumunu, polisiye romanın da çözüme odaklı yanını birleştirerek düşsel ve gerçekdışı olay ya da kişilere anlam kazandırır. Tek bir türden yararlanmayarak polisiye, ütopik ve fantastik romanı eserinde buluşturan Mungan, böylelikle tematik bakımdan zengin bir metin oluşturur.

Bahsettiğimiz kavramlardan beslenerek kendi gezegenini yarattığını ancak kendi gezegenini yaratırken de romanını hayal gücü gösterisine dönüştürmediğini ifade eden Mungan'ın romanında dikkat çeken bir diğer husus, sıkça karşılaştığımız "rüya, düş, sanrı" gibi kavramlardır. Mungan; yarattı̆ğ Gamenn, Ümma ve rüyaları kaydeden rüya terbiyecileri karakterleriyle fantastik romanın ve fantezilerin gerçeği yadsımaya olanak tanıdığını savunan Sigmund Freud'un temelini attığı psikanalitik yaklaşımın bir getirisi olan rüyaya yer verir. Mungan; romanında kâhin ve şair olarak tanıtılan Ümma, atlı polis Gamenn ve insanların rüyalarını kaydeden rüya terbiyecileri yaratır. Gerçek dünyadan 
kaçarak gerçeküstü dünyaya bir kapı açıp romanını hayaller ve rüyalarla süsleyerek anlatır. "Yazar, rüyayla insanın bilinçaltını çıkarmak ve rüyanın insan yaşamını nasıl etkilediğini göstermek ister. Bu noktada Erich Fromm, insan ruhunun en yalın olduğu ve olağanüstü güçlerle de irtibata geçme anının rüyalarla gerçekleştiğini dikkate sunarak, rüyaların aslında bir mesaj dili olduğunu ifade eder." (İlhan 2013: 569) Murathan Mungan'ın insanın ham doğasının dili olarak tanımladığı rüya, roman karakterlerinin hayatlarında önemli bir yere sahiptir. Öyle ki rüya; gördüğü çoğu rüya gerçek çıkan Ümma ve rüyalarında devamlı katili, onun işlediği cinayetleri gören Gamenn için gelecekten gelen bir habercidir. Mungan'ın düş ya da rüya dünyasında kurguladığı fantastik unsurlar içeren romanındaki kehanetler, rüyalar aracılığıyla aktarılır. Bu noktada rüya, Mungan tarafından hem roman kişilerinin belleklerini ve fantezi güçlerini yansıtan hem de merak unsurunu canlı tutarak romana akıcılık kazandiran bir motif olarak kullanılıp başarıyla işlenir.

\section{Sonuç}

Yaratıcılığını sınırlandırmayan ve Türk edebiyatında kendine özgü bir yer edinen Murathan Mungan, eserlerini sezgilerinin 1şığında kaleme alır. Bunu yaparken Doğu ile Batı'nın malzemesini kullanır ve edebiyatı, bir tür varoluş mücadelesi olarak görür. Şiirle alakalı genel görüşlerin yer aldığı ve yapısalcı metodoloji ışı̆̆ında incelediğimiz Şairin Romanı gerek olay örgüsü gerekse kişi kadrosu, zaman ve mekân bağlamında dikkat çeken romanlar arasındadır.

Şiir sanatını merkezine alarak şiirin çeşitli meselelerine değinen bu poetik roman, ayrıca ütopik ve polisiye roman havası da taşır. Öyle ki roman; genelini şairlerin ya da şiir tutkunlarının oluşturduğu bir dünya yaratmasıyla ütopik, şiire ait temel görüşlere yer vermesiyle poetik, roman kişilerinin ve yaşanan olayların olağanüstü özellikler göstermesiyle fantastik, kurbanlarını şairlerden seçen bir katilin yakalanma macerasını anlatmasıyla polisiye özellikler gösteren metinlerarası geçişi sağlayan bir romandır. Diğer bir ifadeyle suçun ve katilin yakalanma serüveninin anlatımında polisiyeden, şiirsiz var olamayacak dünyanın anlatımında da fantastik ve ütopik türden istifade eden Mungan, romanında insan yaşamındaki zıtlıkları ya da çatışmaları yansıtır. Bununla birlikte romandan hikâyeye, şiirden tiyatroya, senaryodan sinema yazısına, denemeden eleştiriye kadar edebiyatın çeşitli alanlarında eserler meydana getirmesi sanatkârın disiplinlerarası geçişler yapmasına olanak sağlar.

Romanın başlığına baktığımızda başlığın olay örgüsünün bütününü kapsayan anlamlar içerdiğini görürüz. Yani romanın ismi ile içeriği arasında derin ve anlamlı bir 
bağ vardır. Başlığında dahi içerik hakkında okuyucunun zihninde önemli çağrışımlar yapan Mungan, Şairin Romanı ile gerçekte olamayacak durum, olay, mekân ve kişilere yer vererek üzerinde yaşadığımız zamanın gerçekliğini çiğner ve okuyucuya farklı bir dünyanın kapılarını açar. İşte Mungan'ın kapılarını açtığı bu dünya, şiirle dolu bir dünyadır. Yüzlü yaşlarında şairleriyle hayalî bir dünya yaratarak varoluşun şiirini anlattığını belirten Mungan için tabiattan kopuş, var oluşun şiirinden kopuşu da ifade eder. Kendi gezegeninden kopan insana tabiatı hatırlatarak kendine has şiirsel üslubuyla dikkat çeker. Sıradanlığın ürkütücü olduğunu düşünen sanatkâr, şiirsel bir anlatımla kaleme aldığı romanında hayatı şiir olarak algılayarak roman dünyasını da şiir üzerine kurgular.

\section{Kaynakça}

\section{Yazılı Kaynaklar}

ALAK, Mustafa (2009). Murathan Mungan'ın Eserlerinde Benlik Araylşı ve Kendini Gerçekleştirme, (Yayımlanmamış Yüksek Lisans Tezi), Yüzüncü Yı1 Üniversitesi Sosyal Bilimler Enstitüsü, Van.

BAYRAKDAR, Sema (2008). Yapısalcılı̆̆a Saussure ile Dilsel Iletişim Açısından Eleştirel Bir Yaklaşım, (Yayımlanmamış Yükssek Lisans Tezi), Atatürk Üniversitesi Sosyal Bilimler Enstitüsü, Erzurum.

BERK, Yusuf ve YILDIRIM, Kasım (2015). "Yapısalc1lı ile Post-Yapısalc1lık Bağlamında Dil ve Metinden Anlam Kurma”, Okuma Yazma Eğitimi Araştırmaları, 3 (2): $39-45$.

BEZEL, Nail (Mayıs 1989). "Ütopya ve Karşı Ütopyalarda Yaşam, Düşünce ve Sinırları", Milliyet Sanat, (216): 2-11.

İLHAN, Nilüfer (Temmuz 2013). “Murathan Mungan'ın Fantastik Bir Polisiye Romanı: Şairin Romanı", International Journal of Social Science, 6 (7): 563-579.

KOCADAYI, Ali (2013). Kaşdişlen Tahtacılarının Dini ve Sosyo-Kültürel Yapısı, (Yayımlanmamış Yüksek Lisans Tezi), Marmara Üniversitesi Sosyal Bilimler Enstitüsü, İstanbul.

MORAN, Berna (2007). Edebiyat Kuramları ve Eleştiri, İstanbul: İletişim Yayınları.

MUNGAN, Murathan (Ağustos 2005). "Hâlâ Sokağa Çıkmak İçin Yazı Yazan Bir Çocuğum", Milliyet Sanat, 96-99. 
MUNGAN, Murathan (2010). Metinler Kitabı, İstanbul: Metis Yayınları.

MUNGAN, Murathan (2011). Şairin Romanı, İstanbul: Metis Yayınları.

OMAY, Murad (2009/1). "Ütopya Üzerine Genel Bir İnceleme”, Sosyoloji Dergisi, (18): 1-14.

SAY, Ömer (2013). "Yapısalc1lıktan Post-Yapısalcılığa Çoğulculuğun İnşası", Akademik Incelemeler Dergisi, 8 (2): 331-346.

ŞABAŞ, Esra Polat (2014). Murathan Mungan'ın Öykü ve Romanlarında Kadın, (Yayımlanmamış Yüksek Lisans Tezi), Adıyaman Üniversitesi Sosyal Bilimler Enstitüsü, Adıyaman.

TAMAY, Sedat (2009). Tahtacı Semahlart ve Mengi (Inceleme ve Metinler), (Yayımlanmamış Doktora Tezi), Ege Üniversitesi Sosyal Bilimler Enstitüsü, İzmir.

TODOROV, Tzvetan (2004). Fantastik: Edebi Türe Yapısal Bir Yaklaşım, çev. Nedret Öztokat, İstanbul: Metis Yayınları.

\section{Elektronik Kaynaklar}

ARMAN, Ayşe (2011). "Hayat Yalan Olduğunda Güzel”. Hürriyet, Erişim Tarihi: 03.04.2019, (http://www.hurriyet.com.tr/hayat-yalan-oldugunda-guzel-17507309).

AKTUĞ, Elif (2011). "Kafam ömrümün yetmeyeceği kadar çok tasarıyla dolu”, Erişim Tarihi: 10.05.2019, (https://www.aksam.com.tr/pazar/kafam-omrumunyetmeyecegi-kadar-cok-tasariyla-dolu--35590h/haber-35590).

BÖREKÇİ, Gülenay (2013). "Murathan Mungan: Sol hülyaları olan bir yazarın ütopyasını yazdım”, Habertürk, Erişim Tarihi: 15.05.2019, (http://egoistokur.com/murathan-mungan-sol-hulyalari-olan-bir-yazarin-utopyasiniyazdim/).

DEMIR, Fethi (2013). “Murathan Mungan'dan Avangart Bir Poetik-Roman: Şairin Romanı”, Erişim Tarihi: $\quad$ 05.04.2019, (https://core.ac.uk/download/pdf/153448845.pdf).

ERCIYES, Cem (Nisan 2011). "Arenayla opera arasında bir hayat benimkisi”, Radikal, Erişim Tarihi: 21.05.2019, (http://www.radikal.com.tr/kitap/arenayla-operaarasinda-bir-hayat-benimkisi-1045625/). 
Zehra YAZBAHAR, “Murathan Mungan'ın Şairin Romanı İsimli Eserinin Yapısalcı Metodoloji Çerçevesinde İncelenmesi”, Mavi Atlas, 7(2)/2019: 28-53

(Temmuz 2015). "Ne aşk ne ejderha kurtarır bu romanı", Radikal, Erişim Tarihi: 21.05.2016, (http://www.radikal.com.tr/yazarlar/cem-erciyes/ne-ask-neejderha-kurtarir-bu-romani-1396166/).

TOSUN, Necip (2012). "Şair Roman Yazarsa”, Hece. Erişim Tarihi: 16.04.2019, (http://tosunnecip.blogcu.com/sair-roman-yazarsa/10158761). 